International Journal of Engineering \& Technology, $7(4.34)(2018) 318-326$
International Journal of Engineering \& Technology
SPC
Website: www.sciencepubco.com/index.php/IJET
Research $p a$

\title{
The Influence of Brand Equity and STP Towards Pricing Strategy and the Impact on Decision Making
}

\author{
Ryan Kurniawan ${ }^{1}$, Mohd Haizam Mohd Saudi ${ }^{1 *}$, Zeffanya Raphael Wijaya ${ }^{2}$ \\ ${ }^{l}$ Widyatama University, Indonesia \\ ${ }^{2}$ Wiyata Indonesia Institute of Management, Indonesia \\ *Corresponding author E-mail: haizam@widyatama.ac.id
}

\begin{abstract}
This research was conducted to find out the influence of brand equity, STP, pricing strategy, and decision making to increase the number of new students every year at the Excellent Class Wiyata Indonesia Management Institute (IMWI) located in Sukabumi City. This is because higher education is one of the driving forces of success of a nation to move forward and able to compete with other nations, then a university should be able to run a quality operational and service, as mandated by law. This research uses an explanatory method, a questionnaire with 5-point scale used to collect data, in order to measure indicators of variables studied. The sample obtained is 163 students, with calculation using Slovin formula, (1) there is an influence of brand equity and STP on decision making, either partially or simultaneously, (2) there is influence of brand equity and STP on pricing strategy, (3) there is an intervening pricing strategy towards decision making. The results of this study are very important for the IMWI Rector to evaluate how to increase the number of students and IMWI images in the minds of the people.
\end{abstract}

Keywords: Brand Equity; STP; Pricing Strategy; Decision Making.

\section{Introduction}

Formal education is currently generally seen as having an important role in the development of Indonesian human resources so that they have good character, have adequate knowledge and expertise to be competitive, both locally and nationally and even internationally. The 1945 constitution amended in Article 28C states: (1) Everyone has the right to develop themselves through the fulfillment of their basic needs, the right to education and to benefit from science and technology, art and culture, in order to improve the quality of their lives and for the welfare of humanity, (2) Everyone has the right to advance himself in fight for their rights collectively to build society, nation and country. The government of the Republic of Indonesia regulates and organizes formal education, starting from elementary and secondary education to higher education. The government also allows the private sector to play a role in the education sector as referred to in Article 28C of the 1945 Constitution. Wiyata Indonesia Foundation felt the need to get involved in the field of higher education on the basis of Article $28 \mathrm{C}$ of the Constitution 45, namely by setting up a college named, Wiyata Indonesia Management Institute (IMWI) in Sukabumi. IMWI wants to play a role in building Indonesia's human resources, especially in Sukabumi and surrounding areas, also as an alternative for students who cannot go outside the Sukabumi area.

The IMWI Rector designed a promotion strategy to support the operational path and at the same time survive competition among universities in Sukabumi. At IMWI, they have an Excellent Class to student candidate to study at IMWI. Excellent class is a class designed specifically to create a superior generation by adding several advantages different from regular classes, for example in this excellent class students are required to be able to speak Eng- lish well with a TOEFL test with a score of 450, in addition they must also have academic achievement which is good as evidenced by the UN and school report cards. The advantages obtained by students are: greater English content with each material delivered in English to the language of instruction (at least mixed with Indonesian). Get additional Mandarin language courses, new students get a semi-military disciplinary orientation before starting lectures. Then, the promotion or marketing department is given a target of 180 Excellent Class students per year according to the capacity of the campus. The number of students is expected to raise sufficient funds for operational costs, in addition to funding support from the foundation.

However, it is unfortunate that apparently the strategy has not been able to influence prospective students to make decisions to become IMWI Excellent Class students, so that the annual target has not been achieved in recent years since 2014 - 2017. Table 1 shows the results achieved since IMWI was established in 2014.

Table 1: Number of Excellent Class Student Achievements 2014-2017

\begin{tabular}{|c|c|c|}
\hline No. & Force Year & Total \\
\hline 1 & $2014 / 2015$ & 121 \\
\hline 2 & $2015 / 2016$ & 67 \\
\hline 3 & $2016 / 2017$ & 45 \\
\hline 4 & $2017 / 2018$ & 41 \\
\hline & Total & 274 \\
\hline
\end{tabular}

Provisional estimates, the problem is caused by the perception of students in decision-making that are affected by the price strategy, brand equity and STP (segmenting, targeting, positioning), which has not been able to attract prospective students. Decision making in general is a final decision of a consumer to buy an item 
or service with certain considerations. In [1] stated that decision making is the process of making decisions and actions of people involved in the purchase and use of products. According to [2], consumer decision making is buying the most preferred brand from various alternatives. It means that someone's condition can make a decision several alternative options must be available.

Brand a product or service will be one of concern and consideration for consumers to decide to buy or not of a product or service of a company. In [2] stated brand equity the value of a brand based on how strong the brand value has the value of brand loyalty, consumer awareness of the brand, perceived quality, brand association, and a variety of other assets such as patents, trademarks and distribution network relationships.

In the paragraph above mentioned that STP (Segmenting, Targeting, Positioning) also used to find prospective students. So, IMWI marketing must be really right to do this strategy. Segmenting market is a process of classifying the entire heterogeneous market into groups or segments that have similarities in terms of the needs, desires, behaviors or responses to specific marketing program [5].

\subsection{Identification of problems}

Based on the background description, there are problems that occur, namely marketing targets that cannot be achieved by the IMWI Marketing Department, as shown by Table 1 with data on the number of students from 2014 - 2017. Even though IMWI implemented the strategy Brand Equity, STP and Pricing Strategy to attract prospective students. So, questions arise that must be answered in this study are as follows:

1. Is Brand Equity influence on Pricing Strategy at Wiyata Indonesia Management Institute?

2. Is STP is influential on Pricing Strategy in Wiyata Indonesia Management Institute?

3. Is Brand Equity influence on Decision Making in Wiyata Indonesia Management Institute?

4. Is STP influence on Decision Making in Wiyata Indonesia Management Institute?

5. Is Brand Equity and STP influence simultaneously against Decision Making in Wiyata Indonesia Management Institute?

6. Is Pricing Strategy influential against Decision Making in Wiyata Indonesia Management Institute?

\subsection{Research purposes}

Based on the research question above, hence the purpose of this research is to know and analyze as follows:

1. Influence of Brand Equity to Decision Making at the Wiyata Indonesia Management Institute.

2. Influence of STP to Decision Making at the Wiyata Indonesia Management Institute.

3. Simultaneous influence of Brand Equity and STP against Decision Making at the Wiyata Indonesia Management Institute.

4. The Influence of Brand Equity on Pricing Strategy at the Wiyata Indonesia Management Institute.

5. The Influence of STP on Pricing Strategy at the Wiyata Indonesia Management Institute.

6. Influence Pricing Strategy to Decision Making at the Wiyata Indonesia Management Institute.

\section{Literature Review}

\subsection{Brand Equity}

Each brand of a product or service in the market generally has a certain value perceived by the producer or consumer. Experts like [3] stated that brand equity is the added value provided by products and services. If customers tend to buy a brand even when faced with competitors who offer superior products, for example in terms of price and practicality, the brand has a high brand equi- ty. In [7] assesses that brand equity is a set of brand assets and liabilities that relate to a brand, its name and symbol which increase or decrease the value provided by an item or service to the company or its customers. In [3] based on the Aaker Model, dividing brand equity into a component of brand awareness, perceived quality, brand association, and brand loyalty.

\subsection{Segmentation Targeting Positioning (STP)}

A business will be more developed and able to achieve the target if it has a good marketing strategy in targeting its consumers. In [8] writes to develop a marketing strategy, three components must be clearly defined:

1. Segmentation or to whom I can sell services.

2. Targeting or to whom I will sell the service that I belong to.

3. Positioning or how I sell the service that I have.

\subsection{Segmentation}

In [3] stated that marketing strategy is an important part of business strategy that gives direction to all management functions of an organization. Basically, modern strategic marketing consists of three main steps, namely segmentation, targeting, and positioning. What is commonly known is Kotler STP. Furthermore, in [4] state that segmentation can be done based on the following dimensions: a. Geographic segmentation, b. Demographic Segmentation, c. Behavioral Segmentation, d. Psychographic segmentation.

\subsection{Targeting}

After evaluating various segments, which segment must be decided and how many segments will be served. In [9] stated as follows, targeting is the process of evaluating segmentation and focusing marketing strategies on a country, province, or group of people who have the potential to respond. Furthermore, in [3] determine the target market of the company which can consider the following five patterns: a) Single Segment Concentration, b) Selective Specialization, c) Product Specialization, d) Market Specialization, e) Full Market Coverage.

\subsection{Positioning}

The determination of the development strategy always begins with positioning. In [11] stated that brand positioning is "The strategy for leading your customers credibly". In [3] stated that positioning is an action plan for bidding and corporate image to occupy a distinctive place in the mind of the target market. In [10] revealed that positioning is not what you do on a product, but what you do to the prospect's mind.

Some product positioning strategies according to Kotler that can be done by companies in marketing their products include: a. Positioning based on Company attributes, b. Positioning based on product benefits, c. Positioning based on usage / application, d. Positioning based on user, e. Positioning based on competitors, $\mathrm{f}$. Positioning based on product categories, g. Positioning based on quality / price.

\subsection{Pricing Strategy}

Consumers in determining the choice of product or service always consider the price, so producers must review the pricing strategy they offer. Understanding pricing strategy according to [12] that pricing strategy is decisions about the price set by management. In [3] the definition of price is the amount of money charged on a product or service, or the amount of value exchanged by consumers for benefits due to having or using a product or service. Pricing Strategy is a decision regarding the prices to be followed for a certain period of time. The following are seven pricing methods according to [3] namely: a, Markup Pricing, b. Target-Return Pricing, c. Value-Pricing Preview, d. Value Pricing, e. Going-Rate Pricing, f. Auction-Type Pricing, g. Group Pricing System. 


\subsection{Decision Making}

In [13] states that what is meant by decision making is the process of integration which combines knowledge to evaluate two or more alternative behaviors, and choose one of them. This understanding is reinforced by [14] states that consumer decision making can be defined as a mental orientation that characterizes the consumer's approach to making choices. The decision-making process of the model is 5 stages [3] among others as follows: a) Introduction to Problems, b) Information Search. c) Alternative Assessment. d) Decision to Buy, e) Behavior after Purchasing.

\subsection{Previous Research}

Several studies have been carried out referring to the theories of experts. For example: in [15] conducted research which showed that the elements of the independent variable Brand Equity had a positive Influence on the dependent variable Decision Making. The results of [17] show that Brand Equity had no significant Influence on Decision Making.

Research on the Influence of STP on Decision Making was carried out by [19]. The results showed that the independent variables of segmenting, targeting and positioning had a significant positive Influence on the dependent variable Decision Making. Another study by [20] found that the results of Decision Making appeared to be influenced by segmentation influences, which were divided into four criteria: demographic (age, sex, religion, family status), geographical (region, country, population), psychographics (style life, personality), behavioristic (the relationship between tourists and products-benefits, the benefits customers expect to get from products)

Research on the importance of the role of Pricing Strategy was carried out by [21], the results showed that the marketing mix in the element of pricing had a significant influence and had a positive relationship to the dependent variable decision making. Different results from the study occurred in [22] with the results of the statistical analysis used can be concluded that the brand is very influential on the decision to buy motorbikes in PT. Subur Plus Indramayu, but the price is not too influential in decision making.

\subsection{Framework}

Research requires a good frame of mind, with the aim of results so that research can meet research standards. This is because the frame of mind provides a conceptual basis for building relationships between variables involved in research.

\subsection{Influence of Brand Equity on Pricing Strategy}

In [24] states that through the financial literature, we know the benefits of working brand value added that contribute to prices. In [23] stated a financial-based approach shows that innovation and brand quality drive brand equity through value propositions, which in turn allows marketers to set premium prices. Brand equity experts' opinions on the pricing strategy above show a hypothesis that:

\section{H1: Brand equity influences pricing strategy.}

\subsection{Influences of Segmentation, Targeting, Position- ing to Pricing Strategy}

Segmentation, Targeting, Positioning contained in the elements of marketing mix generally affects the price determination. In [2] argue that there are two main factors that need to be considered in determining prices namely the company's internal factors and external environmental factors. The company's internal factors include the company's marketing objectives, marketing mix strategies, costs, and organization. Then, the hypothesis can be drawn as follows:
$\mathrm{H} 2$ : Segmentation, Targeting, Positioning influence the pricing strategy.

\subsection{Influences of Brand Equity to Decision Making}

Some experts like [16] argue if consumers assume that a particular brand is physically different from a competitor's brand, the brand image will be attached continuously so that it can form loyalty to a particular brand which will ultimately influence decision making Reasonto buy a brand is a positive attitude and a feeling of influence Purchasing behavior and customer satisfaction are brought by brand association [7]. In [25] stated the better the brand equity of a product that is sold it will have an impact on consumer decision making. Based on the description above, how brand equity is perceived and felt by consumers, the hypothesis developed is as follows:

H3: Brand Equity take Influence at decision making.

\subsection{Influence of Segmentation, Target- ing, Positioning against Decision Making}

In [26] states segmentation in households based on brand responses, promotions, buying events and prices affect decision making. Through the study of domestic and foreign positioning theory, the connotation of brand positioning has an understanding, brand positioning is letting the brand occupies the minds of consumers in a favorable position, with help with the means of communication, build a good brand image to be moved to the mind of the consumers. This is necessary to distinguish the factor criteria that are considered in assessing the attractiveness of the ting segment during target decision making [27]. Exposure of experts can be drawn as follows:

H4: Segmentation Targeting, Positioning affect decision making.

\subsection{Influence of Brand Equity and Segmentation, Tar- geting, Positioning against Decision Making}

Consumer choice decisions can be facilitated by brand equity because there are so many brands in the market that offer similar products with little differentiation, so that it can be difficult for consumers to make choices but brand equity is a tool that can influence decision making [28]. Therefore, branding is the most powerful mental shortcut available to consumers [29]. In [30] stated that decision making is a decision-making process for purchasing which includes determining what to buy or not and the decision is obtained from previous activities. The opinions of these experts in brand equity and segmentation, targeting, positioning STP explained that the hypothesis can be drawn:

H5: Brand equity and Segmentation, Targeting, Positioning (STP) simultaneously affect decision making

\subsection{Pricing Strategy Influences on Decision Making}

Price is generally one of the factors that someone makes a decision to buy something. Research has shown that price is an important factor in decision making, especially for products that are often purchased, which affect choices for shops, products and brands [32]. Research conducted by [31] on the price variable shows that consumer perception of price influences consumer decision making. The importance of price as a purchasing stimulus has a key role in price management because it not only determines how prices are perceived and valued, but also affects consumer decision making. Similarly, research conducted by [33-34] that the competitive price influence on decision making consumer. The opinion of the experts above can show that there is a stimulus so that consumers make decisions, then the hypothesis is drawn: 
H6: Pricing strategy influences decision making.

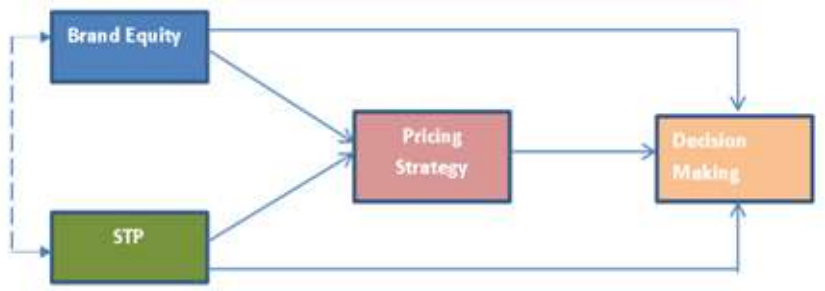

Fig. 1: Analysis and Hypothesis Model

\section{Methodology}

The research method provides an overview of the research design which includes procedures or steps that must be taken, (1) research time, (2) data and information sources, (3) data processing methods, (4) studies and analysis. This was carried out to produce a clearer, more comprehensive and systematic picture of the research.

\subsection{Design and Type of Research}

This research refers to opinions [35] that research design is a series of choices of rational decision making, and issues related to decisions regarding research objectives (exploration, descriptive, hypothesis testing), occasion, the design must be in accordance with (type of investigation), temporal aspect (time horizon), and the level at which data will be analyzed (unit analysis). Type explanatory research used in this study, in [36] states that the explanatory research (explanatory research) is research that has the purpose to explain the position of the studied variables and relationships between variables that one with another variable. This research is based on opinions from [37] is the research field (field research) supported by library research (library research). Excellent data obtained from the research or the field will be analyzed quantitatively refers to the opinions of [38].

\subsection{Research Places and Steps}

The selection of research sites as mentioned in the background section is the Indonesian Wiyata Management Institute (IMWI). According to data from the Higher Education in 2016, IMWI is one of 6 institutes in West Java and only one in the City and Sukabumi districts. Researchers compile the research process such as [35] opinion to design research steps as follows:

\subsection{Population and Sample}

This study refers to [35] which argues that the population is referring to the whole group of people, events or things of interest to be investigated, a collection of sampling units which includes one or more elements. The population in question in this study, are all students of the Wiyata Indonesia Management Institute which amounts to 274 students.

The sample for the study must be taken by a predetermined population. According to [39], if the population is less than 100 people, it is better to take all the population to be sampled, so that the research is population research. The population amounted to 274 students, then the determination of the sample using the formula Slovin with an error rate of $5 \%$. Calculations are as follows.

$$
n=\frac{N}{\left(1+N \cdot e^{2}\right)}
$$

where

$\mathrm{n}=$ Number of samples

$\mathrm{N}=$ Total population

$\mathrm{e}=$ significant level $(5 \%)$

$\frac{274}{1+274(0,05)^{2}}$

$\mathrm{n}=163$ students

\subsection{Variable Research and Operationalization of Vari- ables}

In [35] argues variable is something that can differentiate or bring variation in value. The opinion was reinforced by [43] in his theory that defines that variables are attributes of an individual or an organization that can be measured or observed. The variables studied were 4 as described in chapter 2 as follows:

1. Independent Variable

a. Brand Equity Variable (X1) has 4 dimensions examined based on the opinion of [7] as follows: Brand awareness, Perceived Quality, Brand Association, Brand Loyalty.

b. STP variable (X2) has 3 dimensions based on the thought of [3] as follows: Segmentation, Targeting, Positioning.

2. Dependent Variable Variable Decision Making $(\mathrm{Z})$ with 4 indicators used and will be measured is the thought of [14], which includes the following: Price awareness, Quality awareness, Recreation, Realizing newness

3. Intervening Variables

Variable Pricing Strategy (Y) with 4 indicators used and will be measured is [42] includes as follows: Determination of selling prices, price elasticity, payment methods, price growth.

\subsection{Data analysis method}

Data analysis is a method or method to simplify data into an easily understood form. This study uses path analysis or path analysis. In [41] explains that path analysis is a research method that is primarily used to test the strength of direct and indirect relationships of the independent variables on the dependent variable. This path analysis is based on correlation analysis and regression analysis.

\subsection{Descriptive Analysis Testing}

In [40] explained that descriptive statistics are part of statistics that learn how to collect data and present data so that it is easy to understand. Descriptive analysis is based on the rating scale sought by the range of criteria proposed by [18] based on the percentage of respondents' answers with the following formula.

$$
\% \text { Skor }=\frac{\text { Skor Aktual }}{\text { Skor Ideal }}
$$

where

Actual score $=$ number of respondents' answers

Ideal score $=$ number of maximum scores (number of respondents $\times$ number of statements $\times 5$ )

\subsection{Instrument Testing}

The results of the questionnaire collected until 1 must be proved valid or invalid, then the data is to be tested: validity, reliability. 


\subsection{Classic assumption test}

If classical assumptions are made in order to obtain regression results that can be valid or valid and have definite results. So, the classical assumption test must be done, the tests carried out are as follows:

1. Normality test

2. Multicollinearity Test

3. Heteroscedasticity test

\subsection{Analysis Design}

Analysis is conducted seeing partially and simultaneously influence of variable brand equity, segmentation targeting positioning (STP) to decision making with a pricing strategy as intervening in student IMWI using Path Analysis. Consideration of using path analysis methods is as follows:

1. Path Analysis could explain the relationship and magnitude between research variables that are useful for researchers in knowing more in the various variables studied.

2. Path Analysis is suitable for analyzing causal relationships, can find out the direct or indirect Influences of a number of causal variables on the resultant variables, both partially and simultaneously

3. Path Analysis is suitable for a number of samples of more than 100 respondents and the data processed is exploratory and data can be observed directly in the field [44-45].

The path diagram and structural equation of this research are as shown in Figure 2 as follows:

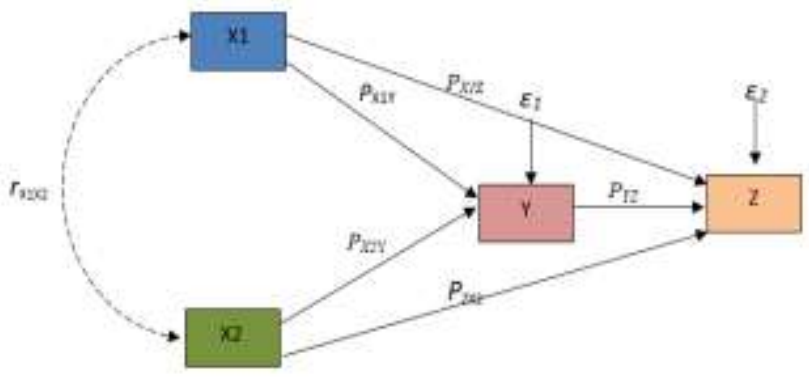

Fig. 2: Path Analysis Equation Model

where

$\mathrm{X}_{1}=$ Brand Equity

$\mathrm{X}_{2}=$ Segmentation Targeting Positioning (STP)

$\mathrm{Y}=$ Pricing Strategy

$\mathrm{Z}=$ Decision Making

$\varepsilon=$ Epsilon

\section{Results and Discussion}

\subsection{Research Instrument Test}

\subsubsection{Validity Test}

The validity of research depends on the research instrument used The research instrument is said to be valid if there are similarities between collected data and empirical data. The validity of the study shows the accuracy and suitability of the research instrument. The higher the validity of a measuring instrument, meaning that the measurement tool is better to use [18].

Validity test results show that all questions have $\mathrm{r}$ count $>\mathrm{r}$ table (0.361), so that each question item variable brand equity, segmentation targeting positioning (STP), decision making, and pricing strategy are declared valid (valid), and none the question item that fall.

\subsubsection{Reliability Test}

The purpose of reliability testing is to prove that the nature of the measuring instrument or research instrument is sufficiently accurate, stable or consistent when used to measure what the researcher wants to measure. Based on the results of the reliability test calculations, each variable has a reliability coefficient value above the Cronbach Alpha coefficient $(\alpha>0.6)$. The reliability value of the Brand Equity variable (X1) has a reliability coefficient of 0.872 , STP (X2) has a reliability coefficient of 0.887 , Pricing Strategy (Y) has a reliability coefficient of 0.778 , and Decision Making (Z) has a reliability coefficient of 0.830 . The four variables are declared reliable because the reliability coefficient value > 0.6 . It is reliable because it can produce accurate and consistent answers.

\subsection{Classic assumption test}

\subsubsection{Normality test}

The normality test is conducted to find out whether the data taken comes from a population that is normally distributed. A good regression model is normally distributed or close to normal. Normality test results showed that the value of Asymp. Sig. (2-tailed) for all variables tested, has a significant value above $(0$, $05)$. In other words, this means that the residual variable normal distribution.

\subsubsection{Multicollinearity Test}

Multicollinearity is something where several or all independent variables or independent variables have a high correlation. Multicollinearity test results, that all test results of independent variables data are free from multicollinearity because they have tolerance above 0,1 and VIF below 10 . This shows that each variable in this model does not occur multicollinearity, meaning that there is no perfect correlation or relationship perfect between the independent variables that make up the equation.

\subsection{Heteroscedasticity Test}

Heteroscedasticity test aims to test whether in the regression model there is a variance inequality from residual one observation to another observation. If the residual variance from one observation to another observation remains, then it is called homoskedasticity. Heteroscedasticity test results that the scatterplot diagrams produced do not form a particular pattern and spread, it can be concluded that regression does not experience heteroscedasticity disorder.

\subsection{Descriptive Analysis}

Description analysis is carried out to describe the respondent's response to each item statement for the variable under study. Brand Equity Calculation (X1) shows that the value obtained is $77.6 \%$, in the high category. STP calculation (X2) shows that the value obtained is $77.8 \%$, in the high category. Pricing Strategy calculation $(\mathrm{Y})$ shows that the value obtained is $65.6 \%$, is in a fairly high category. Decision Making $(\mathrm{Z})$ calculation shows that the value obtained is $74.2 \%$, in the high category.

\subsection{Path Analysis}

4.5.1. Influence of Brand Equity (X1) and Segmentation Targeting Positioning (X2) on Pricing Strategy (Y)

Furthermore, it is in accordance with the research objectives namely to examine the Influence of Brand Equity (X1) and Segmentation Targeting Positioning (X2) on Pricing Strategy (Y). This data processing uses path analysis with the following equation. 
$\mathrm{Y}=\rho_{\mathrm{zx} 1} \mathrm{X}_{1}+\rho_{\mathrm{zx} 2} \mathrm{X}_{2}+\varepsilon_{1}$

where

$\mathrm{Y}=$ Pricing Strategy

$\mathrm{X}_{1}=$ Brand Equity

$\mathrm{X}_{2}=$ Segmentation Targeting Positioning

The first hypothesis that will be tested is the influence of Brand Equity and Pricing Strategy and the second hypothesis is the Influence of Segmentation Targeting Positioning on Pricing Strategy. Based on the results of data processing obtained the path coefficients of each independent variable, namely Brand Equity $\left(\mathrm{X}_{1}\right)$ and Segmentation Targeting Positioning $\left(\mathrm{X}_{2}\right)$ to Pricing Strategy $(\mathrm{Y})$ are shown in the table below.

Table 2: Foreign M - Line Path Coefficients Variables X1 and X2 to Y

\begin{tabular}{|c|c|c|c|c|}
\hline Variabel & Koefisien & thime & P-value & \multirow{2}{*}{$\mathbf{R}^{2}=\mathbf{0 , 6 0 7}$} \\
\cline { 1 - 4 } $\mathrm{X}_{1}$ & 0,332 & 4,382 &, 000 & \multirow{2}{*}{, 000} \\
\cline { 1 - 3 } $\mathrm{X}_{2}$ & 0,497 & 6,553 & \multicolumn{1}{|c}{} \\
\hline
\end{tabular}

Table 2 obtained the total Influence of Brand Equity $\left(\mathrm{X}_{1}\right)$ and Segmentation Targeting Positioning $\left(\mathrm{X}_{2}\right)$ variables on Pricing Strategy (Y) is 0.607 or $60,7 \%$. While, the rest of $39,3 \%$ is the influence of other factors outside of both the independent variables. Visually, the path diagram influences Brand Equity and Segmentation Targeting Positioning towards Pricing Strategy is shown in the following figure.

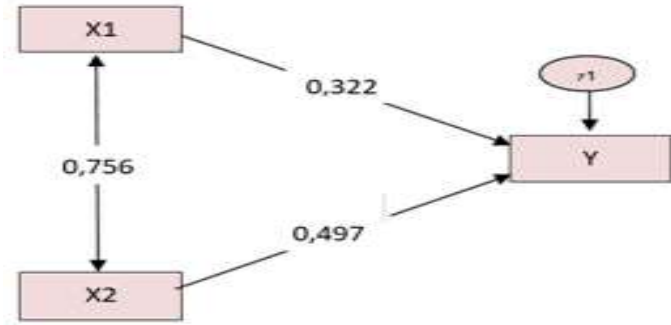

Fig. 3: Path Diagrams (X1) and (X2) to (Y)

Through the values contained in the picture above, it can be calculated the influence of each independent variable (Brand Equity and Segmentation Targeting Positioning) on Pricing Strategy.

$\mathrm{Z}=0.332 * \mathrm{X} 1+0.497 * \mathrm{X} 2$

After the path coefficient is calculated, then to prove whether Brand Equity and Segmentation Targeting Positioning has a significant Influence on Pricing Strategy, the hypothesis is tested.

\subsubsection{Testing of Pathway $X 1$ and $X 2$ Coefficients against $Y$}

Tests are carried out to prove whether Brand Equity Affects Pricing Strategy and Segmentation Targeting Positioning Affects Pricing Strategy. To test the path coefficient of each independent variable used statistic test where the value $\mathrm{t}$ count compared with the value $\mathrm{t}$ table on error rate $\alpha=5 \%$ and degrees of freedom $(\mathrm{db}=\mathrm{nk}-1)=160$ on the testing of two directions is equal to $1.975\left(\mathrm{t}_{\text {table }}=1.975\right)$.

\subsubsection{Testing the Influence of Brand Equity on Pricing Strate-} gy

$\mathrm{H}_{0}: \mathrm{px}_{1}=0$ Brand Equity has no Influence on Pricing Strategy. $\mathrm{H}_{1}$ : $\rho z x_{1} \neq 0$ Brand Equity Influence on Pricing Strategy.
Table 3: Results of Testing the Influence of $\mathrm{X} 1$ on $\mathrm{Y}$

\begin{tabular}{|c|c|c|c|c|c|}
\hline $\begin{array}{c}\text { Koefisien } \\
\text { Jalur }\end{array}$ & $\mathbf{t}_{\text {bitung }}$ & $\mathbf{t}_{\text {tabel(db:160) }}$ & $\mathbf{p}$-value & $\mathbf{H}_{0}$ & $\mathbf{H}_{1}$ \\
\hline 0,332 & 4,382 & 1,975 & 0,000 & Ditolak & Diterima \\
\hline
\end{tabular}

Based on the test results in Table 3 can be seen the value of $t$ count for the Brand Equity variable of 4.382 and $t$ table of 1.975 . Because the $t$ count value (4.382) is greater than $t$ table (1.975) and the $p$-value is 0.000 (less than $0.05 \%$ ) which indicates that it has a high probability, then with $\alpha=5 \%$ it was decided to reject $\mathrm{H}_{0}$, so $\mathrm{H}_{1}$ is accepted. So, based on the test results, it can be concluded that Brand Equity has a significant Influence on Pricing Strategy. Path coefficient value of 0.332 with a positive direction, indicating that the higher the brand equity it will increase the Pricing Strategy.

4.5.4. Testing the Influence of Segmentation Targeting Positioning on Pricing Strategy

$\mathrm{H}_{0}: \mathrm{zx}_{2}=0$ Segmentation Targeting Positioning has no Influence on Pricing Strategy.

$\mathrm{H}_{1}: \rho \mathrm{zx}_{2} \neq \quad$ O Segmentation Targeting Positioning affects the Pricing Strategy.

Table 4: Results of Testing the Influence of X2 to Y

\begin{tabular}{|c|c|c|c|c|c|}
\hline $\begin{array}{c}\text { Koefisien } \\
\text { Jalur }\end{array}$ & tatunt & tateidacise & p-value & $\mathbf{H}_{6}$ & $\mathbf{H}_{4}$ \\
\hline 0,497 & 6,553 & 1,975 & 0,000 & Ditolak & Diterima \\
\hline
\end{tabular}

Based on the test results in Table 4 can be seen the value of $\mathrm{t}$ arithmetic variable Segmentation Targeting Positioning amounted to 6,553 and $t$ table amounted to 1.975. Because the value of $\mathrm{t}$ arithmetic $=6.553$ is greater than the value of $\mathrm{t}$ table $=1.975$ and the p-value value is 0.000 (less than $0.05 \%$ ) which indicates that it has a high probability, then with $\alpha=5 \%$ it is decided to reject $\mathrm{H}_{0}$, so $\mathrm{H}_{1}$ is accepted. So, based on the test results, it can be concluded that Segmentation Targeting Positioning Significant Influence on Pricing Strategy. The path coefficients worth 0.497 with a positive direction, indicating that the higher Segmentation Targeting Positioning it will increase the Pricing Strategy.

4.5.5. Influence of Brand Equity (X1) and Segmentation Targeting Positioning (X2) on Decision Making (Z)

Furthermore, it is in accordance with the purpose of the study, which is to examine the Influence of Brand Equity (X1) and Segmentation Targeting Positioning (X2) on Decision Making $(Z)$. This data processing uses path analysis with the following equation.

$Z=\rho_{\mathrm{zx} 1} X_{1}+\rho_{\mathrm{zx} 2} X_{2}+\varepsilon_{1}$

where

$\mathrm{Z}=$ Decision Making

$\mathrm{X}_{1}=$ Brand Equity

$\mathrm{X}_{2}=$ Segmentation Targeting Positioning

In accordance with the proposed research hypothesis, the data will be tested using path analysis. Path analysis examines the structural causal relationship of the independent variables on the dependent variable by considering the interrelationship between the independent variables.

The third, fourth and fifth hypotheses that will be tested are the influence of Brand Equity and Segmentation Targeting Positioning on Decision Making, both jointly and partially. Based on the results of data processing obtained the path coefficients of each independent variable namely Brand Equity $\left(\mathrm{X}_{1}\right)$ and Segmentation 
Targeting Positioning $\left(\mathrm{X}_{2}\right)$ to Decision Making $(\mathrm{Z})$ are shown in the table below.

Table 5: Individual Path Coefficients Variables $\mathrm{X} 1$ and $\mathrm{X} 2$ for $\mathrm{Z}$

\begin{tabular}{|c|c|c|c|c|}
\hline Variabel & $\begin{array}{c}\text { Koefisien } \\
\text { Jalur }\end{array}$ & $\mathbf{t}_{\text {bitung }}$ & P-value & \multirow{2}{*}{$\mathbf{R}^{2}=\mathbf{0 , 7 3 8}$} \\
\cline { 1 - 3 } $\mathrm{X}_{1}$ & 0,270 & 4,370 &, 000 & \\
\cline { 1 - 3 } $\mathrm{X}_{2}$ & 0,636 & 10,291 &, 000 & \\
\hline
\end{tabular}

Table 5 are obtained total Influence of variable Brand Equity $\left(\mathrm{X}_{1}\right)$ and Segmentation Targeting Positioning $\left(\mathrm{X}_{2}\right)$ of the Decision Making (Z) is equal to 0.738 or $73.8 \%$. While, the rest of $26.1 \%$ is the influence of other factors outside of both the independent variables. Visually a path diagram influences Brand Equity and Segmentation Targeting Positioning towards Decision Making shown in the following figure.

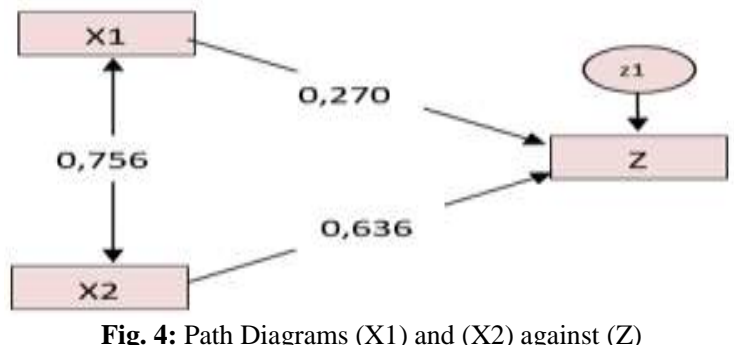

Through the values contained in the figure above can be calculated the Influence of each independent variable (Brand Equity and Segmentation Targeting Positioning) on Decision Making.

$\mathrm{Z}=0.270 * \mathrm{X} 1+0.636 * \mathrm{X} 2$

After the path coefficient is calculated, then to prove whether Brand Equity and Segmentation Targeting Positioning has a significant Influence both partially and simultaneously on Decision Making, the hypothesis is tested. Hypothesis testing starts from partial testing and continues with simultaneous testing (together).

\subsubsection{Testing Partial Coefficients Partially $X 1$ and $X 2$ against Z}

Partial testing is carried out to prove whether partially brand equity and segmentation target positioning affect the decision making. To test the path coefficient of each independent variable used statistic test where the value $t$ count compared with the value $t_{\text {table }}$ on error rate $\alpha=5 \%$ and degrees of freedom $(\mathrm{db}=\mathrm{nk}-1)=$ 160 on the testing of two directions is equal to $1.975(\mathrm{t}$ table $=$ 1.975).

\subsubsection{Testing the Influence of Brand Equity on Decision Mak- ing}

$\mathrm{H}_{0}$ : $\rho \mathrm{zX} 1=0$ Brand Equity has no Influence on Decision Making.

$\mathrm{H}_{1:} \rho \mathrm{zX} 1 \neq 0$ Brand Equity Influence on Decision Making.

Table 6: Test Results of X1 Influence on Z

\begin{tabular}{|c|c|c|c|c|c|}
\hline $\begin{array}{c}\text { Keefisien } \\
\text { Jalur }\end{array}$ & thituag & teatelea:169; & p-value & $\mathbf{H}_{\mathbf{6}}$ & $\mathbf{H}_{1}$ \\
\hline 0,270 & 4,370 & 1,975 & 0,000 & Ditolak & Diterima \\
\hline
\end{tabular}

Based on the test results in Table 6 can be seen the value of $t$ count for the Brand Equity variable of 4.370 and $t$ table of 1.975 . Because the value of $t$ arithmetic (4.370) is greater than $t$ table (1.975) and the $p$ value is 0.000 (less than $0.05 \%$ ) which indicates that it has a high probability, then with $\alpha=5 \%$ it was decided to reject $\mathrm{H}_{0}$, so $\mathrm{H}_{1}$ is accepted. So, based on the test results, it can be concluded that Brand Equity has a significant Influence on Decision Making. Path coefficient value of 0.270 with a positive direction, indicating that the higher the brand equity it will increase the Decision Making.

\subsubsection{Testing the Influence of Segmentation Targeting Posi-} tioning on Decision Making

$\mathrm{H}_{0:} \mathrm{Zzx}_{2}=0$ Segmentation Targeting Positioning has no Influence on Decision Making.

$\mathrm{H}_{1:} \rho_{\mathrm{zx}} \neq$ T Segmentation Targeting Positioning affects the Decision Making.

Table 7: Test Results of X2 Influence on Z

\begin{tabular}{|c|c|c|c|c|c|}
\hline $\begin{array}{c}\text { Koefisien } \\
\text { Jalur }\end{array}$ & $\mathbf{t}_{\text {situgg }}$ & $\mathbf{t}_{\text {tatedidb:ise }}$ & $\mathbf{p}$-value & $\mathbf{H}_{4}$ & $\mathbf{H}_{1}$ \\
\hline 0,636 & 10,291 & 1,975 & 0,000 & Ditolak & Diterima \\
\hline
\end{tabular}

Based on the test results in the table above can be seen the value of $t$ count variable Segmentation Targeting Positioning of 10.291 and $t$ table of 1.975. Because the value of $\mathrm{t}$ count $=10.291$ is greater than the value of $\mathrm{t}$ table $=1.975$ and the $\mathrm{p}$ value value is 0.000 (smaller than $0.05 \%$ ) which indicates that it has a high probability, then with $\alpha=5 \%$ it is decided to reject $\mathrm{H}_{0}$, so $\mathrm{H}_{1}$ is accepted. So based on the test results it can be concluded that Segmentation Targeting Positioning have a significant Influence on Decision Making. The path coefficients worth 0.636 with a positive direction, indicating that the higher Segmentation Targeting Positioning it will increase the Decision Making.

\subsection{Simultaneous Testing}

Simultaneous testing was carried out to prove whether Brand Equity and Segmentation Targeting Positioning together influence Decision Making.

$\mathrm{H}_{0}$ : All $\rho \mathrm{zx}_{\mathrm{i}}=0$ Brand Equity and Segmentation Targeting Positioning have no Influence on Decision Making.

$\mathrm{H}_{\mathrm{a}}$ : There is $\rho \mathrm{zx}_{\mathrm{i}} \neq 0$ Brand Equity and Segmentation Targeting Positioning affect the Decision Making.

Testing the hypothesis is done through $\mathrm{F}$ test statistics with the provisions:

- Reject $\mathrm{H}_{0}$ if $\mathrm{F}_{\text {count }}$ is greater than $\mathrm{F}_{\text {table }}\left(\mathrm{F}_{\text {count }}>\mathrm{F}_{\text {table }}\right)$

- Accept $\mathrm{H}_{0}$ if $\mathrm{F}$ count is smaller or equal to $\mathrm{F}_{\text {table }}\left(\mathrm{F}_{\text {count }} \leq \mathrm{F}\right.$ table $)$

Table 8: Testing Results the Influence of $X 1$ and $X 2$ Terhadap $Y$

\begin{tabular}{|c|c|c|c|c|}
\hline F $_{\text {hitung }}$ & $\mathbf{t}_{\text {tatbel }(d \mathrm{~d}: 2 ; 160)}$ & $\mathbf{p}$-value & $\mathbf{H}_{\mathbf{0}}$ & $\mathbf{H}_{\mathbf{1}}$ \\
\hline 225,581 & 3,053 & 0,000 & Ditolak & Diterima \\
\hline
\end{tabular}

From table $\mathrm{F}$ for the significance level $\alpha=0.05$ and degrees of freedom $(2 ; 160)$ obtained $\mathrm{f}$ table value of 3.053 . The test criteria are, "reject Ho if $F_{\text {count }}>F_{\text {table }}$ ". Because of the test results ob-

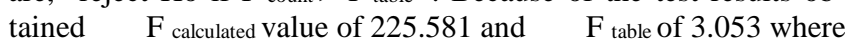
$\mathrm{F}_{\text {arithmetic }}=225.581>\mathrm{F}_{\text {table }}=3.053$, then at $\alpha=5 \%$ it was decided to reject $\mathrm{H}_{\mathrm{o}}$, so that $\mathrm{H}_{1}$ was accepted. So, based on the test results, it can be concluded that Brand Equity and Segmentation Targeting Positioning simultaneously has a significant Influence on Decision Making.

\subsubsection{Influence of Pricing Strategy (Y) on Decision Mak-} ing (Z)

Furthermore, it is in accordance with the purpose of the study, which is to examine the Influence of Pricing Strategy on Decision Making with Decision Making as an Intervening Variable. This data processing uses path analysis with the following equation. 


$$
Z=\rho_{\text {zy }} Y+\varepsilon_{2}
$$

where

$$
X=\text { Pricing Strategy }
$$

\section{$\mathrm{Z}=$ Decision Making}

In accordance with the proposed research hypothesis, the data will be tested using path analysis. Path analysis examines a structural causal relationship from the independent variable to the dependent variable by considering intervening variables (intermediaries).

\subsubsection{Pricing Strategy Influence Testing to Decision Making}

The 6th hypothesis that will be tested is the Influence of Pricing Strategy on Decision Making. Based on the results of data processing obtained the path coefficient of Pricing Strategy on Decision Making can be seen in the table below.

Table 9: Path Y Coefficient against Z

\begin{tabular}{|c|c|c|c|c|}
\hline Variabel & $\begin{array}{c}\text { Koefisien } \\
\text { Jalur }\end{array}$ & thitug & P-value & \multirow{2}{*}{$\mathbf{R}^{2}=\mathbf{0 , 6 3 5}$} \\
\hline $\mathrm{Y}$ & 0,797 & 16,742 &, 000 & \\
\hline
\end{tabular}

Table 9 shows the total Influence of variable Pricing Strategy $(X)$ to Decision Making $(\mathrm{Z})$ is equal to 0.635 or $63.5 \%$. While, the balance of $36.5 \%$ is the influence of other factors outside of Pricing Strategy. The visual path diagram influences Pricing Strategy towards Decision Making shown in the following figure.

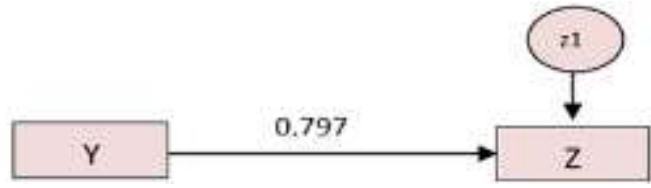

Fig. 5: Path Influence Diagram $Y$ against $Z$

Through the values contained in the picture above can be calculated the influence of the independent variable (Pricing Strategy) on Decision Making.

\section{$\mathrm{Z}=0.797 * \mathrm{Y}$}

After the path coefficient is calculated, then to prove whether Pricing Strategy has a significant Influence on Decision Making, the partial hypothesis is tested.

Hypothesis:

$\mathrm{H}_{0}: \rho \mathrm{x}_{1} \mathrm{Y} \quad$ = 0 Pricing Strategy has no significant Influence on Decision Making.

$\mathrm{H}_{1}: \rho \mathrm{x}_{1} \mathrm{Y} \neq 0$ Pricing Strategy has a significant Influence on Decision Making.

Table 10: Test Results of Y Influence on $Z$

\begin{tabular}{|c|c|c|c|c|c|}
\hline Koefisien Jalur & $\mathbf{t}_{\text {hitung }}$ & $\mathbf{t}_{\text {tabel(db:161) }}$ & $\mathbf{p}$-value & $\mathbf{H}_{\mathbf{0}}$ & $\mathbf{H}_{\mathbf{I}}$ \\
\hline 0,797 & 16,742 & 1.975 & 0,000 & Ditolak & Diterima \\
\hline
\end{tabular}

Based on the test results in Table 10 can be seen the value of $\mathrm{t}$ count the Pricing Strategy variable of 16.742 and $t_{\text {table }}$ of 1.975 where the value of $t_{\text {count }}=16.742>t$ table $=1.975$. Because the value of $t$ count is greater than $t$ table and $p$-value is 0.000 (less than 0.05 ) which indicates that it has a high probability, then with $\alpha=5 \%$ it is decided to reject $\mathrm{H}_{0}$, so that $\mathrm{H}_{1}$ is accepted.

So, based on the test results it can be concluded that Pricing Strategy has a significant Influence on Decision Making. These test results provide empirical evidence that the higher the Pricing Strategy that will improve Decision Making.
4.6.3. D9irect and Indirect Influences of $X 1$ and $X 2$ against $Z$ through Y

\begin{tabular}{|c|c|c|c|}
\hline \multirow[t]{2}{*}{ Variabel } & \multirow{2}{*}{$\begin{array}{l}\text { Pengaruh } \\
\text { Langsung }\end{array}$} & $\begin{array}{c}\text { Pengaruh Tidak } \\
\text { Langsung }\end{array}$ & \multirow{2}{*}{$\begin{array}{c}\text { Total } \\
\text { Pengaruh }\end{array}$} \\
\hline & & Melalui Y & \\
\hline $\mathrm{XI} \rightarrow \mathrm{Y}$ & $0,3,32$ & $\cdot$ & 0,332 \\
\hline $\mathrm{X} 2 \rightarrow \mathrm{Y}$ & 0.497 & - & 0.497 \\
\hline $\mathrm{XI} \rightarrow \mathrm{Z}$ & 0.270 & 0.265 & 0.535 \\
\hline $\mathrm{X} 2 \rightarrow \mathrm{Z}$ & 0,636 & 0,396 & 1,032 \\
\hline $\mathrm{Y} \rightarrow \mathrm{Z}$ & 0,797 & - & 0,797 \\
\hline
\end{tabular}

Table 11: Direct and Indirect Influences

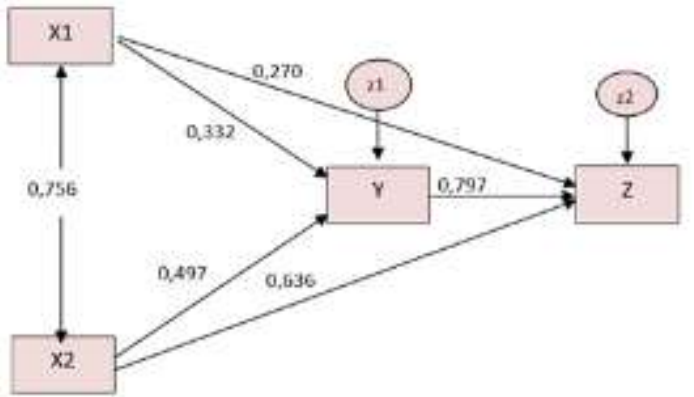

Fig. 6: Influence of $X 1$ and $X 2$ on $Z$ through $Y$

Based on the tables and images in the above it can be seen that:

1. The direct influence of Brand Equity $\left(\mathrm{X}_{1}\right)$ on Pricing Strategy $(\mathrm{Y})$ is 0.332 .

2. The direct Influence of Segmentation Targeting Positioning $\left(\mathrm{X}_{2}\right)$ on Pricing Strategy $(\mathrm{Y})$ is 0.497.

3. The total Influence of Brand Equity $\left(\mathrm{X}_{1}\right)$ on Decision Making $(\mathrm{Z})$ is 0.535 .

4. The total Influence of Segmentation Targeting Positioning $\left(\mathrm{X}_{2}\right)$ on Decision Making $(\mathrm{Z})$ is 1.032 .

5. The direct Influence of Pricing Strategy $(\mathrm{Y})$ on Decision Making (Z) is 0.797 .

\section{Conclusion}

Some of the results of previous studies that differ in relation to decision making, reveal that decision making is influenced by brand equity, STP, and pricing strategy. This study itself shows the answers to the questions that arise in the identification of problems in chapter 1 as follows:

1. The results of the study show that brand equity and STP have a partial Influence on pricing strategy. This means that variations in brand equity and STP values can explain the variation in pricing strategy.

2. The results showed that brand equity and STP affect decision making, both partially and simultaneously. It means that variations in brand equity and STP values can explain the variation in decision making values.

The results show that as an intervening pricing strategy variable influences decision making. This means that variations in pricing strategy can explain the variation in decision making values.

\section{References}

[1] Sangadji EM, Sopiah DM and Pd M. 2013. Perilaku Konsumen Pendekatan Praktis Disertai Himpunan Jurnal Penelitian. Cv Andi.

[2] Armstrong G, Adam S, Denize S and Kotler P. 2014. Principles of marketing. Pearson Australia.

[3] Kotler P and Keller KL. 2012. Marketing Management. Prentice Hall.

[4] Kotler P, Bowen JT and Makens JC. 2002. Pemasaran, perhotelan dan keparawisataan. Prehallindo. 
[5] Tjiptono and Chandra. 2012. Strategic Marketing. Andy Offset.

[6] Lamb CW, Hair JF and McDaniel C. 2011. Essentials of Marketing. Cengage Learning.

[7] Aaker DA. 2009. Managing brand equity. Simon and Schuster.

[8] Tarantino DP. 2003. Using the balanced scorecard as a performance management tool. Physician Executive, 29(5), 69-73.

[9] Iskandar J. 2015. Analisa Penerapan Segmenting, Targeting, dan Positioning Terhadap Strategi Pemasaran. Jurnal. Universitas Tribhuwana Tunggadewi Malang.

[10] Ries A and Trout J. 2013. Positioning: Wie Marken und Unternehmen in übersättigten Märkten überleben. Vahlen.

[11] Kotler P, Kartajaya H and Setiawan I. 2010. Marketing 3.0: From products to customers to the human spirit. John Wiley and Sons.

[12] Saladin D. 2003. Intisari Pemasaran dan Unsur-unsur Pemasaran. Linda Karya.

[13] Setiadi NJ. 2003. Perilaku konsumen: Konsep dan implikasi untuk strategi dan penelitian pemasaran. Prenada Media.

[14] Sprotles GB and Kendall EL. 1986. A methodology for profiling consumers' decision-making styles. Journal of Consumer Affairs, 20(2), 267-279.

[15] Kumar MM, Kumar DP and Narayana MS. 2016. Impact of brand equity on customers purchase decision making while choosing branded over unbranded apparel in Andhra Pradesh. International Journal of Applied Engineering Research, 11(7), 5202-5209.

[16] Rangkuti F. 2015. Marketing Research. Gramedia Pustaka Utama.

[17] Pandensolang JD and Tawas HN. 2015. Pengaruh diferensiasi, kualitas produk dan ekuitas merek terhadap keputusan pembelian Coca-Cola pada PT. Bangun Wenang Beverges Company di Manado. Jurnal EMBA: Jurnal Riset Ekonomi, Manajemen, Bisnis dan Akuntansi, 3(3), 1113-1124.

[18] Sugiyono. 2011. Method Research Quantitative Qualitative and R $\&$ D. Alfabeta.

[19] Karamoy SW. 2013. Strategi segmenting, targeting dan positioning pengaruhnya terhadap keputusan konsumen menggunakan Produk KPR BNI Griya. Jurnal EMBA: Jurnal Riset Ekonomi, Manajemen, Bisnis dan Akuntansi, 1(3), 562-571.

[20] Vinerean A. 2014. Motivators That Intervene in the Decision Making Process in Tourism. Expert Journal of Marketing, 2(2), 6167.

[21] Soedijati EK and Pratminingsih SA. 2011. The impacts of marketing mix on students choice of university study case of private university in bandung, Indonesia. Proceedings of the 2 nd International Conference on Business and Economic Research, pp. 1-8.

[22] Saprudin H. 2015. Pengaruh harga dan merek terhadap keputusan pembelian konsumen sepeda motor di PT. Subur Plus Indramayu. Jurnal Investasi, 1(1), 68-82.

[23] Ailawadi KL, Lehmann DR and Neslin SA. 2003. Revenue premium as an outcome measure of brand equity. Journal of Marketing, 67(4), 1-7.

[24] Barth ME, Clement MB, Foster G and Kasznik R. 1998. Brand values and capital market valuation. Review of Accounting Studies, 3(1-2), 41-68.

[25] Wibowo GSA. 2013. Pengaruh Elemen-Elemen Brand Equity terhadap Keputusan Pembelian Notebook Toshiba. Jurnal Segmen, 9(1), 1-9.

[26] Bucklin RE, Gupta S, Siddarth S. 1998. Determining segmentation in sales response across consumer purchase behaviors. Journal of Marketing Research, 35(2), 189-197.

[27] Goller S, Hogg A, Kalafatis SP. 2002. A new research agenda for business segmentation. European Journal of Marketing, 36(1/2), 252-271.

[28] Gunawardane NR. 2015. Impact of Brand Equity towards Purchasing Desition: A Situation on Mobile Telecommunication Services of Sri Lanka. Journal of Marketing Management, 3(1), 100-117.

[29] Leighton J, Bird G. 2014. The effect of branding on consumer choice.

http://www.packagingfedn.co.uk/images/reports/The\%20Effect $\% 2$ 0of\%20Branding\% 20on\%20Consumer\%20Choice.pdf.

[30] Sofjan AMB. Management Pemasaran. Raja Grafindo Persada.

[31] Dahmiri D. 2010. Analisis Persepsi Konsumen terhadap Keputusan Membeli Perumahan Griya Kembar Lestari di Kota Jambi. Jurnal Manajemen Pemasaran Modern, 14, 36-46.

[32] Rondán Cataluña FJ, García AN, Phau I. 2006. The influence of price and brand loyalty on store brands versus national brands. Int. Rev. of Retail, Distribution and Consumer Research, 16(4), 433452 .
[33] Budiadi, NA 2009. Analisis Pengaruh Persepsi Harga terhadap Perilaku Pembelian Produk Kebutuhan Sehari-Hari. Bisnis dan Kewirausahaan, 2(3)

[34] Narjono, AI 2012. Atribut Produk sebagai Dasar Keputusan Pembelian Susu. Ekonomika, 5(1), 6-11.

[35] Sekaran U, Bougie R. 2016. Research methods for business: A skill building approach. John Wiley and Sons.

[36] Singarimbun M. Effendy Sofyan. 2005. Metode Penelitian Survei. PT Remaja Rosdakarya.

[37] Fowler JW, Streib H, Keller B. 2004. Manual for faith development research. Research Center for Biographical Studies in Contemporary Religion, Universität Bielefeld; Center for Research in Faith and Moral Development, Emory University.

[38] Carmines EG, Zeller RA. 1979. Reliability and validity assessment. Sage Publications.

[39] Arikunto S. 2003. Manajemen. Rineka Cipta.

[40] Hasan I. 2002. Pokok-Pokok Materi Metodologi Penelitian dan Aplikasinya. Ghalia Indonesia.

[41] Sandjojo N. 2014. Metode Analisis Jalur dan Aplikasinya. Universitas Pembangunan Nasional "Veteran".

[42] Tjiptono F. 2014. Pemasaran Jasa-Prinsip, Penerapan, dan Penelitian. Andi Offset.

[43] Creswell JW. 2014. A concise introduction to mixed methods research. Sage Publications.

[44] Sarwono J. 2007. Path Analysis for Business Research with SPSS. Andi.

[45] Kusnendi. 2005. Structural Equation Modeling: Analisis Pemodelan Persamaan Struktural dalam Penelitian Manajemen. Jurnal Manajemen dan Sistim Informasi. Program Studi Pendidikan Manajemen UPI, 2(3), 68-82. 